\title{
Prison Samizdat of British Conscientious Objectors in the First World War \\ Peter Brock
}

Drison samizdat has been described, I think correctly, as "the real prison press" in contrast to the prison press sponsored by, or at least approved by, the jail administration. This samizdat constitutes an underground activity carried on by prisoners "without the sanction of prison officials," and often in conditions of "considerable adversity." The discovery of a samizdat journal is likely to lead to the punishment of those responsible for its production and distribution and the destruction of all copies that the authorities have been able to discover. The unfettered expression of opinion in its pages represents a challenge to the prison establishment that cannot easily be tolerated.

The successful pursuit of prison samizdat journalism requires secrecy above all - the concealment of successive issues of the journal so as to prevent confiscation by the jail authorities. To guarantee this secrecy there is need for the presence within the prison population of a closed and reasonably compact group - political prisoners perhaps, or religious or working-class dissidents among whom the samizdat journal can circulate without the likelihood of a reader, purposely or through negligence, bringing it to the attention of the authorities. Free circulation of the journal among prisoners would almost certainly expose it sooner or later-indeed, probably sooner rather than laterto this danger and thus put an end to the journal's existence. Editor, contributors, and readers of such samizdat are inevitably drawn from one prisoner group, and the contents of the journal will be oriented towards the interests and concerns of this group. The existence in a given prison of a group of this kind presumably explains why samizdat makes an appearance there, since it provides a potential readership for the journal.

Perhaps the most extensive prison samizdat network before mid-twentieth century emerged in World War I Britain among conscientious objectors (COs), incarcerated on account of their resistance to the military conscription introduced there in January 1916. This chapter in the history of "jailhouse journalism" is not, $I$ think, widely known on this continent and it may, therefore, be of interest to readers if I outline the story.

1 Paul Wright in Joumal of Prisoners on Prisons, vol. 10, no. 1/2 (1999), pp. 130, 131; reprinted from Prison Legal News, vol. 10, no. 4) (April 1999). 
In World War I the community of British COs numbered some 16,000 men. It embraced religious pacifists, including active Quaker absolutists who refused all offers of alternative service, as well as humanitarian and socialist war resisters. Those who failed to gain the exemption they wished for from the tribunals, which were set up by the government as part of the administration of conscription and could grant alternative service to COs either in the army's Non-Combatant Corps or in a civilian occupation, were invariably sent to prison. Some of these men served repeated sentences virtually for the same offence. The COs possessed a vigorous organization in the No-Conscription Fellowship. Among the Fellowship's leaders were devout Christian pacifists, like the Quaker Edward Grubb, exempt from call-up because of his age, and socialist pacifists, like Clifford Allen and Fenner Brockway, who both spent prolonged periods in jail for their refusal of military service. ${ }^{2}$ Eventually the government released those imprisoned objectors who were ready to accept work in semi-penal conditions under what was known as the Home Office Scheme. Those men who rejected the Scheme remained in jail even after the war ended in November 1918. Only in April 1919 did the release of these imprisoned objectors begin in earnest; it was completed in the following November. By that date a whole year had elapsed since the conclusion of an armistice between the belligerent powers. $^{3}$

The regimen in British prisons at that date still retained much of the harshness of the penitentiary system introduced by penal reformers in Britain and North America a century or so earlier. ${ }^{4} \mathrm{~A}$ new wave of prison reform originating around the turn of the century had, by 1914, done away with some of the worst horrors of the previous system: the treadmill and crank, the convicts'

2 After the war the two men were eventually raised to the British peetage for political services, in 1932 and 1964 respectively; Lord Allen of Hurtwood died in 1939 and Lord Brockway in 1988. While remaining active in the promotion of peace, by this time both had rejected unconditional pacifism.

3 See Constance Braithwaite, Conscientious Objection to Various Compulsions under British Law (York, UK: William Sessions Limited, 1995), pp. 128-69, for an informative survey of conscientious objection to military service in World War I Britain. To July 31 , $1919, " 5,739$ objectors were sentenced by court martial. 1,548 objectors were sentenced more than once and of these 893 were sentenced more than twice ... . At least 843 objectors were in prison for twenty months or more; some were in prison for more than three years" (lbid., p. 153).

4 The classic account here, so fat as Britain is concerned, is Michael Ignatieff, $A$ Just Measure of Pain: The Penitentiary in the Industrial Revolution, 1750-1850 (New York: Columbia University Press, Morningside Edition, 1980). 
cropped hair, the lock-step movement of prisoners, and some of the more barbarous punishments. But the silence rule, dietary punishment, and the penalty of solitary confinement, as well as the hated broad-arrow prison uniform, remained. And so, of course, did Britain's antique jails constructed in the previous century. COs did not suffer worse treatment in prison than common criminals, but they did endure the same, though some amelioration took place near the end of the war. This, then, was the environment in which the CO samizdat took root and flourished for several years. It ended with the release of the COs.

CO samizdat appeared in at least eight prisons in which COs were confined. Methods of production were similar because the conditions of production did not vary much from jail to jail. No writing materials were then allowed in British prisons, apart that is from a slate with chalk and pen, ink, and form letter issued specifically for the periodic letter home and collected afterwards by one of the warders. Thus these journals had usually to be "written with such fragments of pencil as were obtainable, and in most cases toilet paper was the only paper to be had." They usually appeared "in the form of illustrated magazines." Contents included verse and prose. Humour, a commodity in short supply in jails, occupied a prominent place in both these styles of writing. There were also articles on socialism and pacifism, literature and philosophy, as well as short stories and pencilled sketches. ${ }^{5}$

An anonymous author, writing in 1919, who surveyed this ephemeral press without claiming to have seen all the journals he discussed, let alone all issues of a given journal, calls the Joyland Journal, produced by COs in Mountjoy Prison, Dublin, "undoubtedly ... the most artistic publication" from among the COs' nine known samizdat organs. He describes "its sketches, cartoons, headlines, and cover designs," creations of Arthur Wragg, as "first-class work." (Wragg's antiwar drawings and illustrations became popular in the 1930s in pacifist circles. "The Joyland Journal was bound in cloth, so that in its journey

The C.O. Clink Chronicle (London: National Labour Press, Ltd, [1919]), p. 1. This sixteen-page pamphlet contains extracts from the CO samizdat, mainly verse. While sometimes quite clever or entertaining, they are never of a strikingly high literary calibre. But of course that was not the objective of the writers, who aimed simply at keeping up the spirits of their fellow "conchies" in trying circumstances.

- Ibid., p. 2. I have only been able to trace a single original issue of one of these joumals. (Though more may be extant, toilet paper does not provide the most durable material for purposes of publication!) 
from cell to cell it might be properly preserved." Here, as in the case of the other journals, only one copy was made; this copy then circulated among the prison's CO population. Eventually it would, hopefully, be smuggled out of the prison, probably by the so-called "foot post," by which means letters and pencils were brought by COs into and out of jails.

John Graham, a Quaker prison chaplain who became the first historian of conscientious objection in World War I Britain, tells us that in the course of his duties as chaplain he came into possession of just one issue of a samizdat journal. "The edges of its leaves," he writes, "are tattered, in spite of its cover of sacking decorated with an inscription."

Because of his wartime prison chaplainship and the trust jailed COs placed in him, Graham became well acquainted with the working of their samizdat. We learn from him that its surreptitious circulation from cell to cell "became much more easy under the later [government] regulations, when conversation was allowed [for $\mathrm{COs}$ ] in the exercise yard, and men could walk two or three together." Sometimes a journal might somehow be passed from one cell window to another. For the brown toilet paper, Graham goes on, "prison pen and ink were appropriated as opportunity arose. Leads for writing were imported. Pencils and the precious manuscripts were concealed inside waistbands and the hems of waistcoats. An innocent-looking ball of wax used in the daily work might be discovered to have a movable top, revealing a bottle of ink underneath."

Returning now to our survey of CO samizdat, the Literary Outlet was the product of one W. Dixon's initiative while he was incarcerated in Birmingham and Hull prisons. "It was neatly produced, with artistic coverings, and a number of illustrations were scattered through it." It featured a special series of articles on socialism. Another one-man effort was the Court-Martial, produced in Winchester Prison by a prominent member of the No-Conscription Fellowship,

7 John W. Graham, Conscription and Conscience: A History 1916-1919 (London: George Allen and Unwin, 1922), pp. 280,282. The item owned by Graham was no. 6 of the Winchester Whisperer, Christmas 1918. It is now in the collections of the Library of the Religious Society of Friends, London. Reproductions of it here are by kind permission of this library.

s. Ibid., pp. 279, 280. Graham refers here to a weekly samizdat journal edited by an absolutist CO named Albert Taylor, arrested while a "prospective parliamentary Labour candidate for Rossendale." But I have been unable to identify this paper. See also David Boulton, Objection Overruled (London: MacGibbon and Kee, 1967), p. 228. 


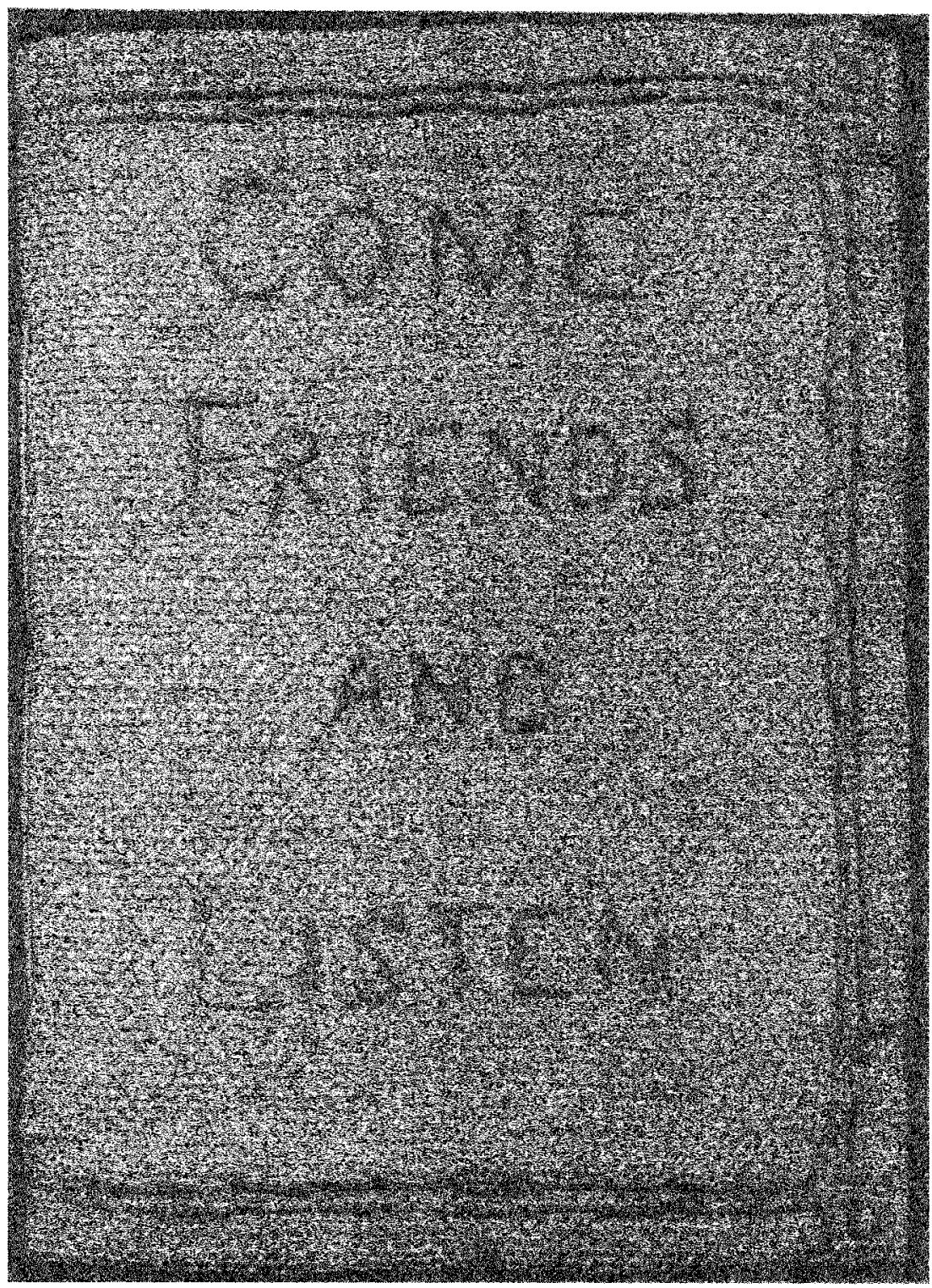

The front cover of the Christmas 1918 issue of the Winchester Whisperer. It is made from 'sacking,' i.e., prison mailbag canvas, and twine. 


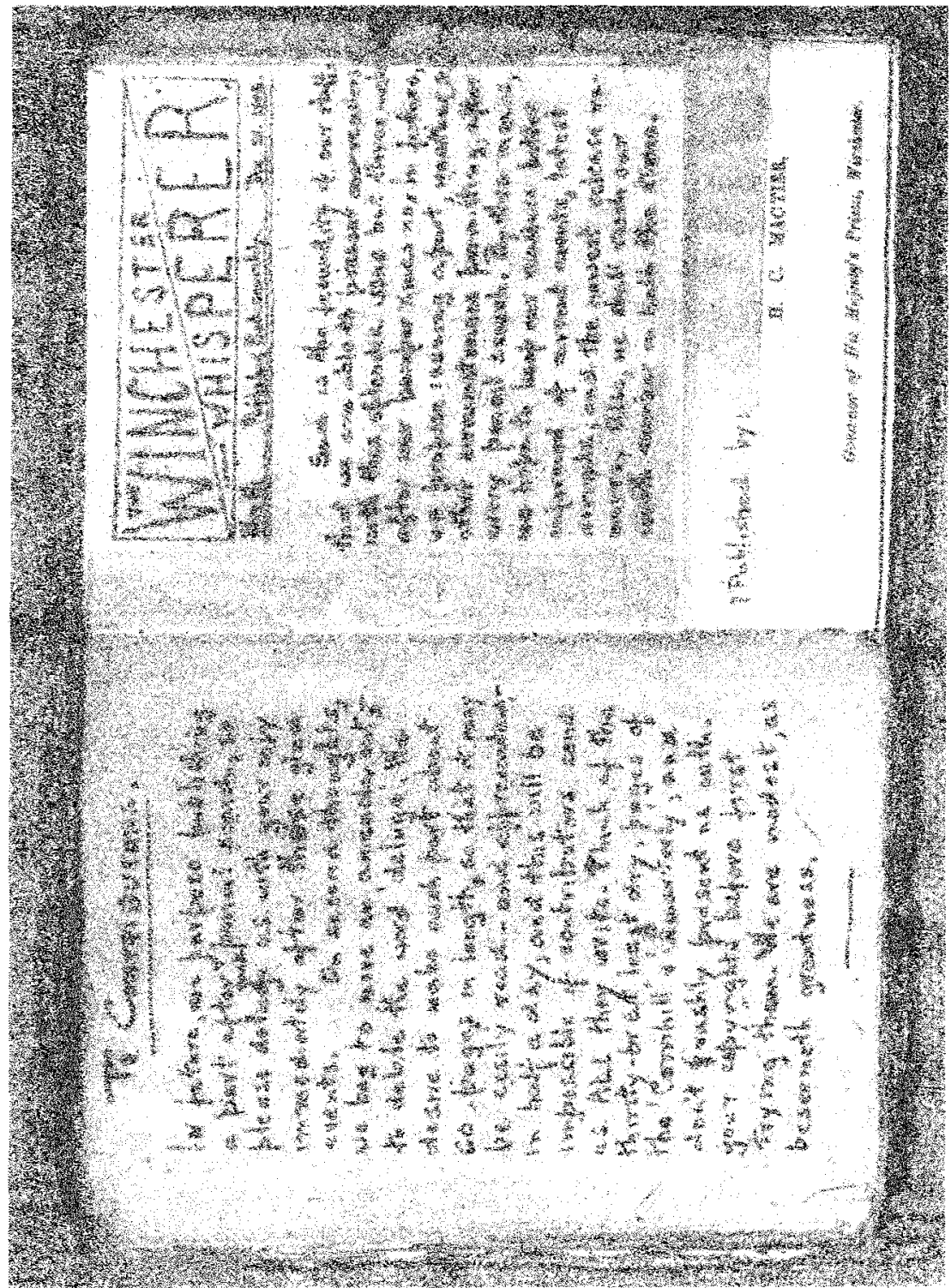

Pages from the Christmas 1918 issue of the Winchester Whisperer. Note the "tattered edges of its leaves" and the humorous attribution of publication to the prison governor. 
W.J. Chamberlain. But it ceased publication after only four issues due to Chamberlain's breakdown under the strain of prison. It was an exclusively humorous magazine, its editor claiming his paper to be "the organ of the Absolutely Its." The pages "were neatly written in imitation print, with a getup similar to that of a smart modern newspaper." Of a size little bigger than a bus ticket, it was perhaps conceived more as a joke than a serious contribution to the prison press. The Lincoln Leader was largely a newssheet, but it included cartoons after the artist, Arthur Wragg, was transferred from Mountjoy Prison in Dublin. The CO samizdat journal produced in Dorchester Prison was unique in that it was written entirely in Esperanto. Entitled Instigilo (Stimulus), "it was well bound in cloth" with excellent illustrations. In fact, "the entire makeup was exceptionally attractive" and up to the standard of the "best monthly magazines," according to one testimony. I wonder, though, how many of the COs then in Dorchester Prison were able to read Esperanto?

The fortnightly Canterbury Clinker was edited by Alfred Barratt Brown, an absolutist Quaker CO who, after the war, became prominent in the adult education movement and was eventually appointed principal of Ruskin College, Oxford, a centre for extra-mural students at that university. Brown composed most of the verses published in the columns of the journal, often parodies of familiar pieces adapted to the conditions of prison life. "The Canterbury Clinker," writes the anonymous author quoted above (who may have been Barratt Brown himself), "was apparently written on the fly-leaves of the editor's books, and since it was done with pen and ink, one concludes that the publication day coincided with his letter-writing day."

About the three remaining CO samizdat journals, the Winchester Whisperer, Old Lags Hansard in Wandsworth Prison, and the Walton Leader in Liverpool, we know rather more than about the other six from the reminiscences of men who participated in their publication and/or circulation.

Let us begin with Winchester Prison's samizdat journal to which its editors gave the title, the Whisperer. Young Harold Bing, serving a lengthy sentence in that jail, reported the following in an interview he gave many years later to the Imperial War Museum Sound Archives, London:

The only writing facility in a cell was a slate and the slate pencil and therefore if you filled your slate you had to rub it all out again. There

9 C.O. Clink Chronicle, pp. 1,2; Boulton, Objection Overruled, pp. 228, 229. 
was no writing material except periodically when you were allowed to have the notepaper in your cell and a pen and ink to write your monthly or fortnightly letter. But here again a little ingenuity was used and some prisoners managed to make little ink wells by taking a block of cobblers wax - which was used for waxing the thread for making mailbags and so on - making a hole in it, sinking a thimble into the wax and then covering it up with another piece of wax. So that what appeared to be a block of wax was in fact a block of wax with a lid and when you lifted the lid there was a thimble sunk into the wax. And that thimble you filled with ink when you had your fortnightly or monthly ink for writing your letter. With inkpots of that kind there was produced in Winchester Prison a periodical called the Winchester Whisperer. It was written on the small brown sheets of toilet paper with which we were supplied - different people writing little essays or poems or humorous remarks, sometimes little cartoons or sketches. And all these bits of paper were passed surreptitiously from hand to hand and reached the editor who bound them together with a bit of mailbag canvas, used for repairing, for a cover, and this issue of the Winchester Whisperer was then passed round secretly hidden under people's waistcoats or up their sleeves. And as it happened, despite many searches, no copy of the Winchester Whisperer was ever captured by the warders, though I think some of them suspected its existence. And all the copies were finally smuggled out and placed in some depository in London, in some library.

I used as a pen a needle, writing with the hollow end - dipping the hollow end into the ink. This meant of course one had to be always dipping the needle into the ink for almost every word. But it did produce thin writing so that you could get a good deal on one small sheet of toilet paper. ${ }^{10}$

The Whisperer was produced in a size easy to conceal from the vigilant eyes of a prison warder: approximately five inches square, it "was bound with mailbag hessian with the title embroidered on the front." Though the writing was small,

10 Quoted in Felicity Goodall, $A$ Question of Conscience: Conscientious Objection in the Two World Wors (Stroud, UK: Sutton Publishing, 1997), pp. 35-37. Bing later became active in the War Resisters' International, especially during the interwar years. What a pity, though, he was not more specific here as to the depository where he says all copies of the CO samizdat smuggled out of the various prisons were to be found! 
young eyes could read it without difficulty. The Whisperer's editor-in-chief was a talented poet and translator, Alan McDougall, who spent over two years in prison as a libertarian $\mathrm{CO}$ until finally, through a prolonged hunger strike, he forced the authorities to release him, by then just "a walking number in misfitting broad-arrows and shuffling shoes." In his memoirs the same friend, who thus described McDougall during their shared sojourn in Winchester Prison, wrote of his paper: "The Winchester Whisperer was, with the exception of Alan McDougall's contributions, great tripe. It was also good fun." His own verse contributions to the paper he modestly categorized as "poor stuff all of it." $\mathrm{He}$ also noted that McDougall allowed him to publish an "unbowdlerized" poem using four-letter words - to the dismay "of that considerable section of Winchester pacifists who were Christians." 11

For information about the samizdat journal of the "conchies" in Wandsworth Prison, where many COs were then incarcerated, I am indebted to a fragment from the hitherto unpublished memoirs of Harold Blake, which has been reproduced by Felicity Goodall in her book on conscientious objectors in the two world wars. Beginning with the paper's editor, whose name unfortunately is not supplied, Blake writes:

He was, in build and feature, almost the double of Mr. Lloyd George. This man undertook the publishing of a newssheet which he designated the Old Lags Hansard. This periodical was written by hand in block characters on sheets of toilet paper, and sewn together with thread; and on account of the labour involved, only one copy of each issue was published. However, it went the rounds passing from hand to hand, and finally when it had fulfilled its intended purpose, it was

1 George Baker, The Soul of a Skunk: The Autobiography of a Conscientious Objector (London: Eric Partridge Ltd. at The Scholars Press, 1930), pp. 199, 200, 253, 254. While McDougall printed classical Greek in his jail samizdat, the imprisoned Quaker pacifist, Stephen Hobhouse, found solace in reading the Greek New Testament in his cell. I had considered this proof of the superior classical culture of an important section of the $\mathrm{CO}$ community in World War I Britain over that of a later generation, as well as over that of COs in North America generally - until I read this: Within recent years George Edwards of Louisville, Kentucky, retired seminary New Testament professor, "taught Greek to some prisoners at $\mathrm{La}$ Grange Prison who had requested the instruction so that they could read the New Testament in its original language. Ray [Cullen, one of the inmates] took the course and did so well that he began teaching Greek to still other prisoners." From Fellowship (Nyack, NY), vol. 66, no. 11-12 (November-December, 2000), p. 25. 
contrived that it should fall into the hands of Mr. Walker, the Chief Warder. The vastly amusing part about the whole business was that the last page always contained the announcement, "Look out for the next number, to be published on ... [date]" and in spite of all the efforts of the authorities to trace its origin, we were not disappointed. Once indeed it was a day late, as they made the declared date a search day; but the editor presented his apologies in his editorial to the effect that he was a day late in publishing "owing to an official raid on our offices." 12

The final CO samizdat journal we have to consider is the Walton Leader. Since its editor was Fenner Brockway, who served his major sentence as a $\mathrm{CO}$ in this Liverpool jail, we are well informed about how this paper functioned, for Brockway included a detailed account of this episode of his variegated political life in both versions of his autobiography that appeared in print during the latter part of his career. ${ }^{13}$

After doing time in Pentonville and Wandsworth and at Wormwood Scrubs, all located in London, Brockway entered Liverpool's Walton Prison in a defiant mood. "T had gone through my period of initiation," he tells us, "and no longer had the spiritual exultation of a novice ... I would pit my wits against those of the authorities and defeat them whenever I could." He considered he had leant a lot from his prison experience. ${ }^{14}$

There were at that time around sixty COs in Walton Prison located in the basement of one of the cellblocks. This concentration of the group made circulation of a samizdat journal easier than if the COs had been scattered in cells throughout the prison. Brockway soon decided it should be his first prison "task" to produce such a paper. The No-Conscription Fellowship had already begun to smuggle leads into prisons concealed in a packet "beneath the arch of the foot" of a $\mathrm{CO}$ entering jail. The leads were useful for passing written messages. "The supreme disability which we had to overcome," writes Brockway, "was the rule forbidding communication between prisoners." Under these conditions "to speak was not always easy." Possession of such leads

12 Goodall, A Question of Conscience, 37.

13. Fenner Brockway, Inside the Left: Thirty Years of Platform, Prison and Parliament (London: George Allen and Unwin, 1942; reprinted New Leader Ltd, 1947), and his second autobiography, Towards Tomorrow (London: Hart-Davis, MacGibbon, 1977). 
greatly facilitated the production of an underground journal, too. ${ }^{15}$ Soon the project got under way. This is how Brockway tells the story:

With a pencil in my hand I immediately began to plan a prison newspaper. The Walton Leader was produced twice a week and was quite a creditable journal. It consisted of about forty toilet paper pages, and included news items, cartoons, serious articles, humorous stories and correspondence. Our cartoonist was Arthur Wragg, whose work is now often to be seen in the press; the news items were sent in by prisoners who had received letters and visits or who had newly come in, whilst articles, stories and letters were contributed in abundance .... We were rapidly becoming experts in breaking the prison rules, and some of the warders, who became increasingly friendly, made this easier by winking their eyes at offences so long as their chiefs did not get to know. ${ }^{16}$

One item in the Walton Leader might have brought us charges under the Official Secrets Act. An incoming objector brought us a detailed account of the slaughter at Passchendaele written by a deserter who was in the guard room at the same time. The story moved us all deeply. Should we complain of our safe conditions whilst others were facing almost inevitable death? One of our boys even withdrew and joined the army because he could not accept the comparison. It was ironical that whilst the Press outside was not allowed to publish the story a prison paper was able to do so. ${ }^{17}$

A copy of the Walton Leader was discovered and I was tried by the Visiting Magistrates. They had no doubt that I produced it and I did not deny it, but they had no evidence. In a normal Court I could not have been found guilty, but they sentenced me to six days on bread and water in the punishment cells. I was taken to a dark basement cell where the furniture consisted of a stool, a chamber pot and a Bible. The second day I became weak and lay on the floor, using the Bible as a pillow, but I found that by the third day I had

Ibid., pp. $95,96$.

Ibid., pp. 98-101.

17 Boulton, Objection Overnled, p. 230, describes this as a "scoop." "At a time when such reports were prohibited in the national newspapers, a tiny prison jounal told in graphic terms of the wave upon wave of 'cannon fodder' sent 'over the top' by the generals, suffering decimation for the sake of a few feet of land - or a cow-shed." 
become adjusted. At night I was permitted to lie on a bed board, which was at least warmer than the stone floor. ${ }^{18}$

The Walton Leader was a more ambitious effort than any other CO prison samizdat of that period. Indeed over a hundred issues were produced. In its commentary on political events, whether at home or abroad, the journal naturally reflected its editor's socialism. But Brockway, while greeting with enthusiasm the fall of the Romanov dynasty in February 1917, was extremely critical of the Provisional Government's continued prosecution of the war.

The paper, until its discovery by the authorities, bore clearly the imprint of its editor's personality. "I used to spend hours in the production of the prison paper," Brockway tells us in his autobiography, "re-writing in small, neat capital letters every contribution, leaving only the cartoons in the original form."19

The reader's subscription, one piece of toilet paper for each issue, ${ }^{20}$ was collected by the cleaner on the landing where the COs were located (a young Welsh CO nicknamed "Raj") when prisoners were at work. "And," writes Brockway, "each evening I found my supply made up plentifully." But, he goes on:

... with the distribution side of the paper I was dissatisfied; to pass a copy from prisoner to prisoner took a week and news and articles became stale. The solution of this difficulty came to me suddenly. We all used the lavatory and in privacy: why not make it the reading room for the paper? I hid it there and tapped out a telephone pipe "Call to all Cells" announcing that it would be there every Tuesday and Thursday morning. I ought to have anticipated the result. On Tuesday and Thursday mornings there were queues; if a prisoner were unlucky enough to get the wrong cubicle, he was back again before long. The prison authorities were puzzled. Why Tuesdays and Thursdays? The Medical Officer was ordered to report on the diet on Mondays and

Brockway, Towards Tomorrow, pp. 51, 52. Brockway, Inside the Left, p. 99.

20 Described by Brockway as "a primitive but very useful form of payment." From his introduction (p. 4) to The Flowery 1942-4: The Scrubs "Conchie" Review (London: Central Board for Conscientious Objectors, 1945). This pamphlet contains excerpts from the samizdat journal produced by COs incarcerated in Wormwood Scrubs Prison during World War II. 
Wednesdays ... but, alas, before his report was prepared the Walton Leader was discovered by an unusually inquisitive or officious warder. ${ }^{2 !}$

Thus one of the most interesting ventures in prison samizdat came to a sudden end.

In the First World War COs in Britain during the period from mid-1916 to mid-1919 had produced at least nine samizdat journals. There may well have been more such papers, now lost, for toilet paper is fragile and the network readership was volatile. There were indeed a number of other prisons in which COs were incarcerated in varying numbers. What, then, of Wormwood Scrubs, Reading, Exeter, Bristol, Norwich, Cardiff, Strangeways (Manchester), Armley (Leeds), Durham, and a number of other jails? And what of the Scottish prisons? But if samizdat was produced by COs in any of these institutions, it has seemingly vanished without a trace. A key factor in producing these journals appears to have been the presence in a given prison of at least one individual with journalistic talent, ready first to take the initiative and then to oversee the journal's production and distribution. Without such a person, presumably a samizdat journal would not emerge, even if other favourable factors such as a sizeable group of COs within the given institution might be present.

One last point is worth noting: the elitist character of this $\mathrm{CO}$ samizdat. It did not circulate among the general prison population, but only among a small group with special concerns of its own, to which the contributors addressed themselves in what they wrote for these journals. I have explained the reasons for this restricted circulation and appeal. I believe they were valid ones; at the same time the elitism of this samizdat should not be slurred over. So far as I know, $\mathrm{CO}$ samizdat did not circulate either among the Irish nationalists incarcerated in British jails during World War $I$, even though Fenner Brockway at any rate was in contact with them. But, then, of course, they possessed a tightly organized communications network of their own.

The $\mathrm{CO}$ underground press described in this essay, hopefully, may prove to be helpful in illuminating prison samizdat as it has developed in Britain and North America since 1950.

21 Brockway, Inside the Left, pp. 99, 100. 
Peter Brock is a previous contributor to the $J P P$ (Volume 11) and a Professor Emeritus at the University of Toronto. He served a six-month sentence in Wandsworth and Wormwood Scrubs Prisons in Britain in 1941-1942 as a conscientious objector during World War II. Peter can be contacted at the Department of History, University of Toronto, 100 St. George Street, Toronto, Ontario, Canada M5S 3G3. 